\title{
DISFUNGSI SEKSUAL PADA PASIEN GAGAL GINJAL KRONIS
}

\author{
Sexual Disfunction in Chronic Kidney Failure Patients
}

Akhyarul Anam ${ }^{\text {** }}$
Sahrudi $^{2}$
*IUniversitas Jenderal
Soedirman, Purwokerto, Jawa
Tengah, Indonesia
2STIKES Abdi Nusantara, Kota
Bekasi, Jawa Barat, Indonesia
*email:
akhyarulanam@gmail.com:

Kata Kunci:

Disfungsi seksual

Gagal ginjal kronis

Kualitatif

Keywords:

Sexual dysfunction

Chronic kidney failure

Qualitative

\begin{abstract}
Abstrak
Gagal ginjal kronis berdampak pada masalah fungsi seksualitas (disfungsi seksual) yang cenderung memburuk dengan penurunan fungsi ginjal. Penelitian ini bertujuan mengkaji secara mendalam terhadap respon individu dalam menghadapi disfungsi seksualnya. Penelitian ini menggunakan metode penelitian kualitatif dengan pendekatan studi kasus single case design melalui wawancara semi terstruktur. Sampel diambil dengan teknik purposive sampling pada pasien gagal ginjal kronis yang mengalami disfungsi seksual. Data diolah dengan metode thematic content anlysis. Tema utama yang ditemukan antara lain disfungsi ereksi, tindakan yang dilakukan untuk masalah disfungsi seksual, respon dalam menghadapi disfungsi seksual, serta harapan terhadap pelayanan kesehatan. Terapi alternatif tradisional dilakukan, namun tidak ada hasil yang nyata. Partisipan berespon secara positif seperti berpasrah, meningkatkan aktivitas spiritual, dan menyadari usia yang sudah tua. Pelayanan kesehatan untuk masalah disfungsi seksual sangat diharapkan.
\end{abstract}

\begin{abstract}
Chronic kidney failure affects sexual function problems (sexual dysfunction) which tends to worsen with decreased kidney function. This study aimed to explore in depth the response of individuals in dealing with sexual dysfunction. This study used qualitative research methods and case study approach with a single case design through semi-structured interviews. Samples were taken by purposive sampling technique in patients with chronic kidney failure who experience sexual dysfunction. Data is processed by thematic content anlysis method. The main themes found include erectile dysfunction, actions taken for sexual dysfunction problems, responses to face of sexual dysfunction, as well as expectations for health services. Traditional alternative therapy is done, but there are no significant results. Participants response positively such as giving in, increasing spiritual activity, and being aware of old age. Health services for sexual dysfunction problems are highly expected.
\end{abstract} This is Open Access article under the CC-BY-SA License (http://creativecommons.org/licenses/by-sa/4.0/). DOI: https://doi.org//0.33084/jsm.vxix.xxx.

\section{PENDAHULUAN}

Gagal ginjal kronis (GGK) merupakan penurunan fungsi ginjal selama tiga bulan atau lebih. GGK dapat berdampak secara sistemik termasuk masalah fungsi seksualitas (disfungsi seksual) yang cenderung memburuk dengan penurunan fungsi ginjal (Sabanciogullari \& Tas, 2015). Disfungsi seksual secara luas didefinisikan sebagai sebuah gangguan dalam siklus respon seksual atau rasa sakit terkait dengan hubungan seksual (Moreau et al., 2016).

Terdapat 85,6\% pasien GGK mengalami masalah disfungsi seksual, dengan frekuensi terbanyak pada stadium 3 (48,4\%), sedangkan disfungsi seksual berat terjadi paling banyak pada stadium 5 (32,9\%). Disfungsi seksual yang terjadi diantaranya $21 \%$ ejakulasi dini, $5 \%$ disfungsi ereksi, dan sisanya berupa penurunan hasrat seksual. Pada perempuan didominasi oleh penurunan hasrat seksual yaitu sebesar $22 \%$, diikuti kesulitan dalam memulai hubungan seksual sebesar $14 \%$, dan $7 \%$ mengalami nyeri saat hubungan seksual (Sabanciogullari \& Tas, 2015).

Banyak hal yang mempengaruhi masalah seksualitas pasien GGK seperti masalah hormonal, gangguan saraf, penurunan energi, dan efek samping akibat pengobatan (Lessan-pezeshki \& Ghazizadeh, 2008). Beberapa pasien dan pasangan merasa khawatir bahwa hubungan seksual dapat membahayakan akses dialisis sehingga menurunkan hasrat seksual (Tannor et al., 2017). 
Kondisi GGK sering menyebabkan oklusi aliran darah arteri dan vena penis yang menyebabkan ketidakmampuan ereksi secara persisten. Aterosklerosis pada regio panggul juga menurunkan aliran darah ke area genital yang dapat menurunkan libido. Masalah hormonal yang turut memengaruhi adalah penurunan produksi cairan semen, oligozoospermia, azospermia. Analisis histologis jaringan testis menunjukkan penurunan aktivitas spermatogenik dan spermatosit akibat uremia yang mempengaruhi steroidogenesis kelenjar gonad, sehingga terjadi penurunan konsentrasi testosteron bebas dalam darah (Makarem et al., 20I I).

Diketahui sebanyak 50\% pasien GGK mengatakan mengalami penurunan libido, berkurangnya kemampuan untuk orgasme, dan menurunnya frekuensi koitus (Basok et al., 2009). Pasien GGK melakukan hubungan intim cukup jarang yaitu dua minggu sekali atau sebulan sekali dan seringkali mengeluhkan nyeri dan kehilangan hasrat seksual. Masalah disfungsi seksual pasien GGK terjadi dengan frekuensi yang hampir sama baik pada laki-laki maupun perempuan dan harus sama-sama mendapat perhatian (Arslan \& Ege, 2009).

Pemenuhan kebutuhan seksual pada dasarnya bersifat holistik dan dipengaruhi berbagai faktor seperti perkembangan, gaya hidup, kondisi kesehatan, peran dan hubungan, persepsi, nilai, budaya, pengalaman sebelumnya, dan koping. Faktor ini menjadi stimulus dalam pemenuhan kebutuhan seksual dan sekaligus menjadi strategi adaptasi jika suatu saat terjadi disfungsi seksual pada individu. Kondisi seksualitas yang sehat menunjukkan gambaran kualitas kehidupan manusia, terkait dengan perasaan paling dalam, akrab, dan intim (Santos et al., 2012).

Studi pendahuluan didapatkan hasil 7 pasien (5 laki-laki dan 2 perempuan) dari 8 pasien GGK (5 laki-laki dan 3 perempuan) mengalami disfungsi seksual dengan kategori ringan (2), sedang (3), dan berat (2). Dari 7 partisipan tersebut telah terdiagnosis GGK bervariasi dari 5 bulan hingga 5 tahun. Mayoritas (80\%) pasien lakilaki mengalami disfungsi ereksi sebagai keluhan utama, dan pada perempuan sebanyak 50\% mengeluhkan penurunan hasrat seksual. Beberapa partisipan berusaha untuk mencari penyembuhan disfungsi seksual melalui pengobatan alternatif yang dipromosikan melalui media elektronik maupun cetak, sementara yang lain cukup berpasrah diri dengan keadaan saat ini.

Studi tentang disfungsi seksual pada pasien GGK masih terbatas dilakukan. Peneliti memandang terdapat fenomena menarik yaitu partisipan yang berusaha mendapatkan kembali fungsi seksualitasnya meski dalam keadaan sakit gagal ginjal kronis. Peniliti ingin melakukan studi lebih mendalam pada pasien GGK yang mengalami disfungsi seksual.

\section{METODOLOGI}

\section{Alat dan bahan}

Populasi penelitian adalah pasien gagal ginjal kronis yang mengalami disfungsi seksual, dengan sampel $T n$. $X$. Kriteria inklusi meliputi usia minimal 18 tahun, terdiagnosis gagal ginjal kronis, mengalami disfungsi seksual dengan skor IIEF (International Index of Erectile Function) $<25$. Intrumen tersebut telah valid dan reliabel, dikembangkan oleh Rosen et al., (1997). Pengambilan sampel dilakukan dengan teknik purposive sampling yaitu sesuai dengan tujuan penelitian.

\section{Metode pelaksanaan}

Penelitian ini menggunakan metode penelitian kualitatif dengan pendekatan studi kasus single case design yaitu dengan mengamati satu subjek penelitian yang unik dan penting secara menyeluruh (Yin, 1989). Data diambil melalui wawancara semi terstruktur dan catatan lapangan. Instrumen penelitian dalam studi kualitatif adalah peneliti sendiri, dengan bantuan pertanyaan wawancara antara lain: Apa saja disfungsi seksual yang anda alami? Bagaimana Anda merespon terhadap disfungsi seksual? Apa yang Anda lakukan untuk mengatasi disfungsi seksual? Data kualitatif diolah 
dengan metode thematic content analysis (Polit \& Beck, 2012).

\section{HASIL DAN PEMBAHASAN}

Partisipan adalah seorang laki-laki berusia 45 tahun yang telah dua tahun terdiagnosis GGK. Sejak saat itu partisipan juga mengalami keluhan penurunan fungsi seksualitasnya. Saat dilakukakn wawancara, didapatkan skor IIEF I 0 yang menunjukkan penurunan fungsi seksual sedang. Partisipan mengungkapkan kebiasaan buruk sebelumnya diduga menjadi penyebab GGK seperti sering mengkonsumsi minuman berkarbonasi dan juga hipertensi yang dialami sekitar 2 tahun sebelum terdiagnosis GGK. Partisipan mendapatkan terapi hemodialysis sejak terdiagnosis GGK. Informasi karakteristik partisipan dapat dilihat pada tabel I di bawah ini.

Tabel I. Data karakteristik partisipan

\begin{tabular}{|c|c|c|c|c|c|c|}
\hline Usia & $\begin{array}{l}\text { Jeni } \\
\text { s } \\
\text { kela } \\
\text { min }\end{array}$ & Pendidikan & Pekerjaan & $\begin{array}{l}\text { Sko } \\
r \\
\text { IIEF }\end{array}$ & $\begin{array}{l}\text { Lama } \\
\text { terdiagnos } \\
\text { is GGK }\end{array}$ & $\begin{array}{l}\text { Lama } \\
\text { disfungsi } \\
\text { seksual }\end{array}$ \\
\hline $\begin{array}{l}45 \\
\text { tah } \\
\text { un }\end{array}$ & $\begin{array}{l}\text { Lak } \\
\text { i- } \\
\text { laki }\end{array}$ & Sarjana & $\begin{array}{l}\text { Pegawa } \\
\text { i } \\
\text { BUMN }\end{array}$ & $\begin{array}{l}10 \\
\text { (sed } \\
\text { ang) }\end{array}$ & 2 tahun & 2 tahun \\
\hline
\end{tabular}

Hasil analisis tematik ditemukan terdapat empat tema utama yang akan didiskusikan berikut ini.

\section{Disfungsi ereksi}

Dari hasil wawancara mendalam didapatkan informasi bahwa partisipan mengalami penurunan disfungsi ereksi sejak awal terdiagnosis GGK. Keluhan tersebut tidak pernah membaik sampai saat ini. Disfungsi ereksi yang dirasakan menjadikan partisipan kurang mempunyai hasrat untuk seksual. Berikut pernyataan partisipan:

"lya, sulit bangun (ereksi) lah pokoknya. Nggak bisa tegang, nggak kuat."

Hasil penelitian mengungkapkan disfungsi seksual yang dialami berupa disfungsi ereksi. Studi Drüeke dan Massy (2010) menemukan pasien laki-laki paling banyak mengalami kesulitan dalam mencapai dan mempertahankan ereksi yaitu sebesar 65\%. Faktor paling erat kaitannya adalah fungsi sirkulasi darah dan kadar testosteron. Disfungsi ereksi pada pasien GGK dapat disebabkan oleh aterosklerosis yang terjadi pada pembuluh darah area genital. Dilatasi arteri kavernosus sangat memiliki peran dalam proses ereksi, sehingga pada pasien gagal ginjal sering mengalami disfungsi ereksi.

Kasus disfungsi ereksi pada pasien gagal ginjal kronis sebanyak $86,4 \%$ dengan distribusi kasus berat $25,4 \%$, sedang 35,4\%, ringan 24,6\%. Disfungsi ereksi menurut IIEF termasuk salah satu domain disfungsi seksual pada laki-laki. Disfungsi ereksi dapat berupa ketidakmampuan organ kelamin untuk ereksi, ataupun ketidakmampuan organ kelamin dalam mempertahankan ereksi sampai terjadi koitus (Wassersug et al., 2016).

Faktor risiko yang turut mempengaruhi skor IIEF pada domain fungsi ereksi adalah umur ( $p$ value $<0.05)$, hemoglobin $(p$ value $<0.05)$, urea $(p$ value $<0.001)$, kreatinin $(p$ value $<0.00 \mathrm{I})$, dan lamanya dialisis $(p$ value <0.05) (Ali et al., 2005). Studi lainnya menyebutkan anemia akibat gagal ginjal dan hiperprolaktinemia, turut menyebabkan disfungsi ereksi. Sebuah studi kohort pada kelompok laki-laki GGK, disfungsi seksual akibat anemia dapat dikoreksi dengan terapi eritropoietin secara disiplin selama minimal tiga bulan (Makarem et al., 20 I I). Hasil yang kontra ditemukan dalam penelitian Cerqueira et al. (2002) bahwa tidak ada hasil yang signifikan antara anemia dan disfungsi ereksi. Hal tersebut terjadi karena responden dalam penelitiannya $77 \%$ telah mendapatkan terapi ertitropoietin selama lebih dari satu tahun sebelum dilakukan penelitian dan $90 \%$ dari responden juga menunjukkan level hematokrit dan hemoglobin yang normal $(\mathrm{Ht}>32 \%$ dan $\mathrm{Hb}>\mathrm{ll} \mathrm{g} / \mathrm{dl})$. Fakta tersebut tetap meyakinkan bahwa adanya anemia adalah suatu faktor risiko terjadinya disfungsi ereksi. Penggunaan eritropoietin yang berkepanjangan mungkin menyebabkan responden dalam penelitian tersebut berperilaku seperti pasien normal yang tidak mengalami disfungsi ereksi. 


\section{Tindakan yang dilakukan untuk masalah disfungsi seksual}

Partisipan pada saat awal mengalami keluhan disfungsi seksual pernah mencoba menjalani terapi alternatif tradisional yang disiarkan di radio swasta. Partisipan merasa tertarik untuk mencobanya. Fase awal telah dicoba selama enam bulan, namun ternyata tidak ada hasilnya. Partisipan merasa ini hanya penipuan saja, karena dengan biaya yang besar namun tidak ada hasil sama sekali. Partisipan mengaku tidak akan mencobanya lagi. Berikut penuturannya:

"Alternatif juga pernah, di Karanganyar itu yang pintu rel itu kan disiarkan di radio begitu hebatnya. Saya tahu infonya dari Radio.. hahaha (tertawa). lyah sampe selesai ga ada pengaruhnya"

Banyak orang beralih ke pengobatan tradisional setelah frustrasi dengan hasil pengobatan modern. Pasien memilih untuk lebih mengeksplorasi berbagai macam praktik tradisional dan alternatif. Metode ini pada umumnya menggabungkan unsur tubuh, pikiran dan jiwa, dan penyembuhan dicapai melalui konsep energi, bukan menggunakan konsep materi seperti dalam pengobatan modern (Ho et al., 20I I). Masyarakat masih banyak yang beranggapan bahwa pengobatan medis untuk disfungsi seksual dapat menyebabkan efek samping yang membahayakan seperti stroke dan penakit jantung, sehingga masyarakat beralih ke pengobatan alternatif.

Dwiyanto (2008) berpendapat, masyarakat kultur Jawa masih memegang adat yang kuat mengenai masalah seksualitas. Pengobatan alternatif dan ramuan tradisional Jawa telah lama dikenal sejak tahun 1814 masehi yang ditulis dalam Serat Centhini karya Pakubuwono V. Karya tersebut memuat berbagai pelajaran-pelajaran penting yang membahas masalah perjodohan dan seksualitas. Masyarakat adat Jawa banyak yang percaya terhadap nilai-nilai dan ajaran dari leluhur yang termuat dalam Serat Centhini tersebut. Beberapa ramuan yang sering digunakan dalam mengatasi masalah disfungsi seksual menurut adalah ginseng, pasak bumi, kunyit, garam, cabe jawa, cangkang telur ayam kate, dan purwoceng.

\section{Respon dalam menghadapi disfungsi seksual}

Partisipan dalam merespon perubahan dalam kehidupannya mampu beradaptasi secara posistif. Perasaan menerima terhadap keadaan, menyadari kondisi kesehatannya, dan mampu berpasrah diri membuat partisipan merasa lebih nyaman, seperti penuturan berikut ini:

"Makannya saya pasrah Alloh, udah terserah Alloh yang penting saya berbuat baik, saya bisanya tinggal dzikir minta ampun dan berdoa, gitu aja. Saya juga menyadari, usia sudah bukan seperti pengantin baru lagi. "

Hasil penelitian ini menunjukkan respon partisipan dalam proses adaptasinya menggunakan cara positif. Kepasrahan partisipan termasuk dalam kategori adaptasi positif, karena dengan kepasrahannya partisipan tidak merasakan beban dan dapat menikmati hidupnya. Yılmaz dan Özaltın (20II) dalam studi fenomenologinya menemukan enam partisipan menganggap disfungsi seksual yang mereka alami adalah suatu takdir dan kehendak Tuhan sehingga pasrah dengan tetap mensyukuri agar dapat terhindar dari rasa putus asa dan depresi. Mereka beranggapan usia yang sudah tua juga turut berpengaruh terhadap penurunan fungsi seksualitas.

Mekanisme respon adaptasi yang dipilih individu akan menjadi efektif bila didukung oleh keyakinan diri sendiri. Tidak semua individu dapat dengan mudah menggunakan strategi koping adaptif dalam menghadapi stresornya. Rentang waktu yang lama dalam menghadapi stresor sangat berpengaruh. Individu yang memiliki pandangan negatif, ketidakberdayaan, keputusasaan, dan tidak adanya semangat dalam hidup membuat individu melakukan koping yang maladaptif (Pilger et al., 2016). 
Sistem dukungan (support system) dalam adaptasi secara positif dapat terbentuk dari keluarga, teman, kelompok, dan Tuhan. Aktivitas spiritual turut menjadi pendukung dari proses adaptasi positif yang dialami partisipan dalam menghadapi stresornya berupa disfungsi seksual akibat GGK. Dalam penelitian ini aktivitas spiritual dilakukan partisipan adalah dengan memperbanyak mengingat Alloh, memperbanyak berdzikir, dan memasrahkan diri kepada Alloh atas segala kondisi yang sedang dijalaninya. Menurut Pilger et al. (2016) dalam studi nya menemukan bahwa dalam upaya keluar dari stressor, partisipan berupaya berdialog dengan Tuhan dan merefleksikan makna dan tujuan dari kehidupan mereka.

\section{Harapan terhadap pelayanan kesehatan}

Partisipan memiliki harapan agar terdapat sarana pelayanan kesehatan yang mampu melayani dan mengatasi masalah disfungsi seksual. Partisipan menuturkan sebenarnya banyak pasien GGK yang sering hemodialysis bersama, ternyata juga memiliki keluhan disfungsi seksual. diantara mereka juga menginginkan adanya solusi yang nyata dari rumah sakit. Kebanyakan pasien mengaku malu, dan perawat juga tidak membuka komunikasi tentang keluhan disfungsi seksual pasien GGK. Berikut penuturannya:

"Klinik tentang disfungsi seksual penting, penting, perlu. Di sini ada belum ya? Biar mengetahui atau kalau bisa mengatasi. Wong kaya gitu tuh kan malu ngomongnya, padahal ya penting, justru harus kita cari."

Partisipan berharap perawat terlebih dahulu membuka komunikasi menanyakan keluhan fungsi seksual pasien GGK. Perbedaan perspektif masalah seksualitas antara petugas kesehatan dan pasien menjadi salah satu penyebab tidak dibicarakannya masalah seksualitas, termasuk masalah budaya, dogma, dan etik (Saunamäki \& Engström, 20/4). Hal tersebut menunjukkan perhatian tenaga kesehatan khususnya perawat belum terlihat dalam membantu klien dalam menghadapi masalah kebutuhan seksualitasnya.
Selama ini pengobatan alternatif yang diiklankan di radio, televisi, dan media lainnya hanya sarana untuk mendapatkan keuntungan saja. Biaya yang dikeluarkan tidaklah sedikit, bahkan bisa mencapai belasan juta hingga puluhan juta rupiah sedangkan hasilnya belum tentu terjamin. Pasien hanya dipengaruhi promosi dan marketing yang pada akhirnya pemberi layanan tersebut hanya mengambil keuntungan.

Penelitian Saunamäki et al. (2010) membuktikan hioptesis bahwa tenaga profesional kesehatan tidak memberikan perawatan yang cukup terhadap kesehatan seksual klien. Sebanyak $86 \%$ responden mengakui bahwa mereka tidak memberikan perawatan yang cukup, dan $92 \%$ responden sama sekali tidak pernah memulai membahas permasalahan ini dengan klien. Terdapat beberapa faktor yang mempengaruhi, antara lain kurangnya pengetahuan mengenai masalah seksualitas, malu, budaya, kurangnya pengalaman dalam merawat pasien, kurangnya pemahaman agama terkait masalah seksualitas, dan perawat merasa malu untuk menangani isu-isu seksual klien (Hollup, 2014).

Pasien mengharapkan informasi yang jelas tentang masalah seksualnya dari tenaga kesehatan. Kejelasan informasi membuat pasien lebih siap secara mental dalam menghadapi masalah-masalah yang terjadi dalam keluarganya, terutama hubungannya dengan pasangan (Sabanciogullari \& Tas, 20I5). Saat ini masalah kesehatan seksualitas masih menjadi hal yang tabu untuk dibahas karena merupakan masalah yang sangat privasi bagi setiap individu. Hal ini penting bagi perawat dalam melaksanakan tugasnya sebagai pemberi asuhan keperawatan yang holistik termasuk masalah seksualitas. Perawat harus memiliki pengetahuan yang luas dan pengalaman yang cukup dalam menghadapi masalah disfungsi seksual, khususnya yang diakibatkan oleh gagal ginjal kronis (Evans, 20I3).

Fennell dan Grant (2019) mengidentifikasi hambatan terjadi karena perasaan malu pada kedua belah pihak. Perawat mungkin kurang memiliki keahlian yang professional dalam menghadapi kasus-kasus disfungsi 
seksual. Krebs mencatat bahwa perawat menganggap hal tersebut bukanlah bagian dari tanggung jawab mereka. Pasien juga seringkali mengira bahwa perawat hanya berfokus pada masalah pengobatan dan perawatan penyakit saja. Perawat harus memiliki beberapa area keahlian untuk meningkatkan pelayanan keperawatan terkait kebutuhan seksualitas klien, yaitu: a) pengetahuan mengenai masalah seksualitas pada aspek sosiokultural perkawinan dan masyarakat, b) kemampuan dalam melakukan penilaian seksualitas dan mediasi, c) kesadaran atas nilai-nilai, kepercayaan, dan perilaku, dan d) pemahaman terhadap faktor-faktor yang mempengaruhi persepsi pasien terhadap masalah seksualitas (Rowniak \& Selix, 2016).

\section{KESIMPULAN}

Pasien GGK dapat mengalami disfungsi seksual seperti disfungsi ereksi sebagai akibat dari proses penyakit. Partisipan berusaha mengatasi masalah disfungsi seksualnya dengan menjalani terapi alternative tradisional, namun tidak ada hasil yang nyata. Partisipan berespon secara positif terhadap disfungsi seksual, misalnya dengan berpasrah, meningkatkan aktivitas spiritual, dan menyadari usia yang sudah tua. Fasilitas pelayanan kesehatan untuk menangani masalah disfungsi seksual sangat diharapkan oleh partisipan.

\section{UCAPAN TERIMA KASIH}

Peneliti mengucapkan terima kasih kepada partisipan dan RSU PKU Muhammadiyah Gombong yang telah bersedia bekerja sama untuk tujuan pengembangan ilmu keperawatan.

\section{REFERENSI}

I. Sabanciogullari, S., \& Tas, F. 2015. Sexual Function in Patients with Chronic Renal Failure on Hemodialysis and lts Effects on Patients Perception of Health and Life Satisfaction. 175-186. https://doi.org/| 0.1007/s I | |95-015-9398-4

2. Moreau, C., Kågesten, A. E., \& Blum, R. W. 2016.
Sexual dysfunction among youth: an overlooked sexual health concern. BMC Public Health, I6(I), I10. https://doi.org/10.1186/s 12889-016-3835-x

3. Lessan-pezeshki, M., \& Ghazizadeh, S. 2008. Sexual and reproductive function in end-stage renal disease and effect of kidney transplantation. 10(3), 44I-446. https://doi.org/10.1 I I I/j. I745-7262.2008.00348.x

4. Tannor, E. K., Archer, E., Kapembwa, K., Van Schalkwyk, S. C., \& Davids, M. R. 2017. Quality of life in patients on chronic dialysis in South Africa: A comparative mixed methods study. BMC Nephrology, I8(I), I-9. https://doi.org//0.1 186/s 12882-016-0425-I

5. Makarem, A. R., Karami, M. Y., \& Zekavat, O. R. 2011. Erectile dysfunction among hemodialysis patients. International Urology and Nephrology, 43(1), I 17-123. https://doi.org//0.1007/s ||255-0109780-I

6. Basok, E. K., Atsu, N., Rifaioglu, M. M., Kantarci, G., Yildirim, A., \& Tokuc, R. 2009. Assessment of female sexual function and quality of life in predialysis, peritoneal dialysis, hemodialysis, and renal transplant patients. International Urology and Nephrology, 4I(3), 473-48I. https://doi.org/ | 0.1007/s I | 255-008-9475-z

7. Arslan, S. Y., \& Ege, E. 2009. Sexual experiences of women exposed to hemodialysis treatment. Sexuality and Disability, 27(4), 215-221. https://doi.org/|0.1007/s | I |95-009-9|32-I

8. Santos, P. R., Júnior, J. R. F. G. C., Cavalcanti, J. U., Vieira, C. B., Rocha, A. R. M., Apolônio, N. A. M., \& de Oliveira, E. B. 2012. Quality of life among women with sexual dysfunction undergoing hemodialysis: a cross-sectional observational study. Health and Quality of Life Outcomes, 10, 1-5. https://doi.org/10.1186/1477-7525-10-103

9. Rosen, R. C., Riley, A., Wagner, G., Osterloh, I. H., Kirkpatrick, J., \& Mishra, A. 1997. The international index of erectile function (IIEF): A multidimensional scale for assessment of erectile dysfunction. Urology, 49(6), 822-830. https://doi.org//0.1016/S0090-4295(97)00238-0

10. Yin, R. K. 1989. Case Study Research. Sage Publications.

II. Polit, D. F., \& Beck, C. T. 20I2. Nursing research: Generating and assessing evidence for nursing practice (9th ed.). Wolters Kluwer, Lippincott Williams \& Wilkins.

12. Drüeke, T. B., \& Massy, Z. A. 2010. Atherosclerosis in CKD: Differences from the general population. Nature Reviews Nephrology, 6(12), 723-735. https://doi.org/10.1038/nrneph.2010.143 
13. Wassersug, R. J., Westle, A., \& Dowsett, G. W. 2016. Men's Sexual and Relational Adaptations to Erectile Dysfunction After Prostate Cancer Treatment. International Journal of Sexual Health, $0(0)$, I-II. https://doi.org/10.1080/19317611.2016.1204403

14. Ali, M. E. M., Abdel-Hafez, H. Z., Mahran, A. M., Mohamed, H. Z., Mohamed, E. R., El-Shazly, A. M., Gadallah, A. M., \& Abbas, M. A. 2005. Erectile dysfunction in chronic renal failure patients undergoing hemodialysis in Egypt. International Journal of Impotence Research, I7(2), I80-185. https://doi.org//0.1038/sj.ijir.3901 286

15. Cerqueira, J., Moraes, M., \& Glina, S. 2002. Erectile dysfunction: Prevalence and associated variables in patients with chronic renal failure. International Journal of Impotence Research, I4(2), 65-7I. https://doi.org/10.1038/sj.ijir.39008I I

16. Ho, C. C., Singam, P., Hong, G. E., \& Zainuddin, Z. M. 20II. Male sexual dysfunction in Asia. Asian Journal of Andrology, 13(4), 537-542. https://doi.org/10.1038/aja.2010.135

17. Dwiyanto, D. 2008. Ensiklopedi serat centhini. Panji Pustaka.

18. Yılmaz, M., \& Özaltın, G. 20II. The sexual behaviors of patients receiving peritoneal dialysis treatment. Sexuality and Disability, 29(1), 21-32. https://doi.org/10.1007/s I I I95-0I I-9199-3

19. Pilger, C., Molzahn, A. E., Pilotto de Oliveira, M., \& Kusumota, L. 2016. The Relationship of the Spiritual and Religious Dimensions with Quality of Life and Health of Patients with Chronic Kidney Disease: An Integrative Literature Review. Nephrology Nursing Journal : Journal of the American Nephrology Nurses' Association, 43(5), 4I I-426.

20. Saunamäki, N., \& Engström, M. 20l4. Registered nurses' reflections on discussing sexuality with patients: Responsibilities, doubts and fears. Journal of Clinical Nursing, 23(3-4), 531-540. https://doi.org/I0.1 I I I/jocn. I 2155

21. Saunamäki, N., Andersson, M., \& Engström, M. 2010. Discussing sexuality with patients: Nurses' attitudes and beliefs. Journal of Advanced Nursing, 66(6), 1308-1316. https://doi.org/10.1 I I I/j.13652648.2010 .05260 .

22. Evans, D. T. 20/3. Promoting sexual health and wellbeing: the role of the nurse. Nursing Standard (Royal College of Nursing (Great Britain): 1987), 28(10). https://doi.org/I0.7748/ns2013.II.28.10.53.e7654

23. Fennell, R., \& Grant, B. 2019. Discussing sexuality in health care: A systematic review. Journal of
Clinical Nursing, 28(17-18), 3065-3076. https://doi.org// 0.I I I I/jocn. 14900

24. Rowniak, S., \& Selix, N. 2016. Preparing Nurse Practitioners for Competence in Providing Sexual Health Care. Journal of the Association of Nurses in AIDS Care, 27(3), 355-36I. https://doi.org/10.1016/j.jana.2015.1 I.010 